\title{
Pre-Triassic Swallow-holes in the Haematite District of Furness, Lancs : a Glimpse of an Ancient Landscape.
}

By Bernard Smith, M.A., F.G.S.

(Published by permission of the Director of the Geological Survey.)

A POINT of economic importance, as well as scientific interest, $A$ has been brought out by a study of the occurrences of hæmatite in the Furness district of Lancashire and the neighbouring shores of the River Duddon in the Millom district of Cumberland; namely, that the origin and distribution of the ore-bodies, known as "sops", is due, in large measure, to the physiographical conditions that existed in this area in post-Carboniferous but preNew Red times. Future explorations for these profitable ore-bodies may be guided by a true appreciation of the conditions of formation, which are discussed, in somewhat scattered form, in the recently published Geological Survey Memoir" on the "Hæmatites of West Cumberland, Lancashire, and the Lake District".

The following is a more connected resumé of the events that gave rise to the sops and the reasons for their restricted occurrence.

We may preface our remarks by stating that (1) the hæmatite found in the Carboniferous Limestone, both in Cumberland and Furness, is due to a metasomatic alteration of the Limestone, presumably by the descent of iron-bearing solutions stored in the New Red beds that overspread the Carboniferous rocks; and (2) "sops" may be defined as bodies of ore, circular to oval in form, and narrowing downwards irregularly like deep basins or pockets in limestone.

It appears that in pre-New Red times the main mass of Carboniferous Limestone formed a widespread plateau extending from near Kirksanton, north-west of Millom in Cumberland, eastward to near Lindal-in-Furness, and was dominated on the south by a northward-facing escarpment of Yoredale Beds. South-west of Dalton-in-Furness the escarpment looped southward to near Yarlside and Stank, as a sharp V-shaped notch, the eastern wall of which was a pre-New Red fault-scarp trending from north to south.

At the present day swallow-holes and caverns are abundant on such limestone plateaux, and as fast as the swallows go out of commission, or the cavern-roofs collapse, they become choked with débris, mostly of an angular and open character, and occasionally roofed with turf. So also in this case swallows were formed, and when a hole ceased to serve as an open conduit, material falling from the walls filled the bottom with coarse limestone débris, and included masses of limestone-shales. Disintegrated shale and mud, washed in, formed a rough lining to the whole mass, and in some cases formed a clayey plug at the bottom. The foot of the escarpment, also, became the depository of screes or brockrams as

1 Special Reports on the Mineral Resources of Great Britain, vol. viii, 1919. 
the escarpment slowly receded under the action of weathering agents.

In New Red times both the plateau and escarpment were overspread by characteristic deposits of dolomitic limestone and breccias (both local), red sands, clays, and shales, relics of which still survive in several places, even where there has been great denudation. In the Newton and Yarlside Mine, in the V-shaped notch above mentioned, the old pre-Triassic fault-escarpment has the irregular outline of a present-day limestone cliff, with the New Red Sandstone still banked against it.

At some post-Triassic date the area was upheaved, faulted, and subjected to denudation.

Since the uplift the Yoredale Beds have been worn back by erosion almost 2 miles to their present position near Adgarley and Little Urswick. Farther south they have retreated less. Towards the Duddon shores they are faulted down beneath New Red Sandstone and do not appear at the surface.

The uplift further resulted in the downward movement of ironbearing waters, which attacked the limestone-breccias in the swallows and caverns, or the limestone along faults and joints.

The mineralizing solutions, entering from above, were concentrated chiefly upon the limestone-breccias, which by nature are peculiarly vulnerable. As the alteration of the limestone fragments progressed the masses of newly formed ore packed together and led to the collapse of the roof and let in the overlying New Red sands and loams in jumbled masses. This episode is recorded in the irregular pockets of such material that are found in the ore of the Park and Roanhead Mines. ${ }^{1}$

That the above is probably the true story receives confirmation from the following facts : (i) After removal of the ore the limestone walls, in some cases, show a smoothing that is characteristic of the action of water, and presumably was effected before the ore was formed. (ii) The sops are lined with "hunger" and "muck". The former is partly composed of weathered shale like that interbedded with the limestone, while the "muck" is probably derived from the ore itself. (iii) Patches of limestone shales are found embedded sporadically in the pure ore. (iv) The ore in the centre of each sop is good soft pick-ore, in small fragments, just such as would be formed from a loose breccia that packed together during alteration. (v) Lastly, a mass at least 122 feet in thickness near its centre, composed of chocolate-coloured clay like a cave earth, and containing many subangular waterworn fragments of limestone, has been found recently, filling the bottom of the Nigel Pit sop at Roanhead, beneath the main mass of ore. It also contains small sandstone fragments and patches of hunger and muck.

In Furness, therefore, the area in which "sops" may be expected

1 Summary of Progress for 1916: Mem. Geol. Surv., 1917, pp. 9-10.

voL. LVII. - NO. I. 
to occur is constituted by the limestone-plateau, some 7 to 8 square miles in extent, north of the old Yoredale escarpment.' To the south and east of the escarpment the ore occurs usually only in vein-like form, and the existence of large bodies of ore becomes less probable with increased distance from the escarpment and a correspondingly increased thickness of cover of Yoredale Beds, which acted as a screen between the iron-bearing solutions and the limestone.

Ore in sop-like form is also likely to occur in the Limestone beneath the Duddon Sands north of Sandscale, and to a less extent perhaps in the Millom area north of Haverigg.

In the sop area (excluding the Duddon shores, where exploration is proceeding) the ore-bodies usually come up to the surface, or to the base of the Glacial drift, and presumably most of these (somewhere near 100) have been located. Some, however, may have remained undetected in the belt where both sops and "veins" occur most freely-i.e. on the line of the foot of the old Yoredale escarpment from the south-east of Dalton as far as the LindalWhinfield district. Moreover, some of the old mines might pay to reopen, for they were abandoned owing to trouble with water or poor demand for ore.

In the area where the vein-like ore-body is predominant, south and east of the old escarpment, deep cross-cuts may prove reserves, as in one case where not only is an old vein being worked in depth but new ore-bodies have been discovered.

\section{Brachiopod Nomenclature: The Genotype of Spirifer}

By S. S. Buckman.

TN this Magazine, August, 1919, p. 371, Dr. J. Allan Thomson 1 has an article on the above subject, in which he appears to be expressing the hope that Spirifer cuspidatus may not be taken as the genotype of $S$ pirifer, though he thinks that certain rules of zoological nomenclature drive him to that conclusion.

It is all very well for zoologists to draw up rules with regard to nomenclature, but they can get tied up with them; and then fresh rules must be made to interpret the former, which may go on ad infinitum. Nowadays in science as in politics we are hung up with too many rules. Rules breed rules, and the worse they are the more they breed. So the fewer rules the better. But there is one rule necessary in nomenclature-read the original diagnosis and try to give effect to the author's intention, so as to fit it to modern requirements.

Why is $S p$. cuspidatus to be the genotype of Spirifer? Because it is the first species mentioned. That may be denied, but if it were

1 The course of this escarpment is shown in pl. iii of the memoir. 